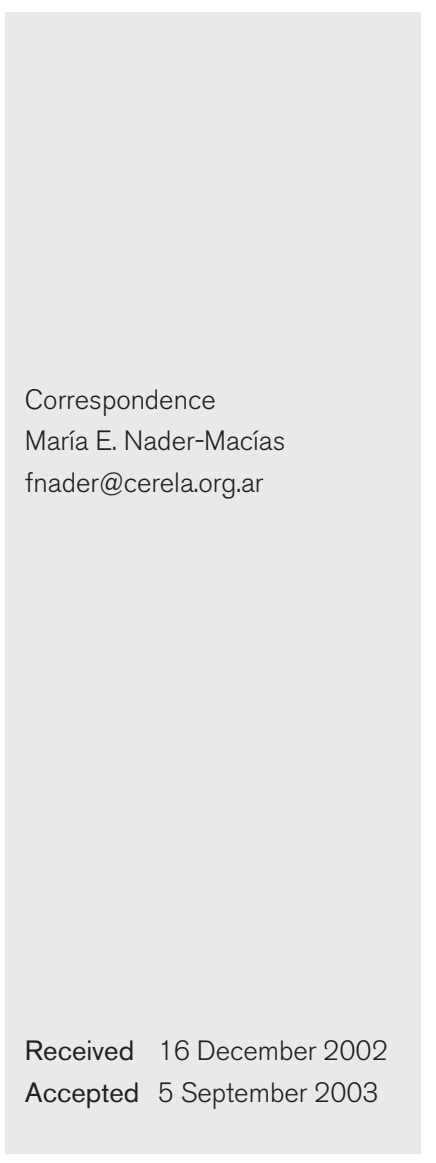

\section{Growth and lactic acid production by vaginal Lactobacillus acidophilus CRL 1259, and inhibition of uropathogenic Escherichia coli}

\author{
María Silvina Juárez Tomás, ${ }^{1}$ Virginia S. Ocaña, ${ }^{1}$ Birgitt Wiese ${ }^{2}$ and \\ María E. Nader-Macías ${ }^{1}$ \\ ${ }^{1}$ CERELA-CONICET (Centro de Referencia para Lactobacilos), Chacabuco 145, 4000, Tucumán, \\ Argentina \\ ${ }^{2}$ Institute of Biometrics, University Hospital, Hannover, Germany
}

\section{INTRODUCTION}

In the vaginal tract, high levels of oestrogens stimulate the deposit of glycogen in the epithelia, which is then fermented to acetic and lactic acids by epithelial cells and/or vaginal flora (Paavonen, 1983). Recent studies support the hypothesis that vaginal bacteria are the primary source of lactic acid in the vagina (Boskey et al., 1999, 2001). Lactobacilli have been recognized as the predominant microflora of the healthy human vagina to maintain a $\mathrm{pH}$ of $<4.5$ (Redondo-López et al., 1990). This low $\mathrm{pH}$ reduces the risk of colonization by pathogens (Stamey \& Kaufman, 1975; Stamey \& Timothy, 1975; Hanna et al., 1985; Tevi-Bénissan et al., 1997). Bacterial vaginosis, the most common vaginal pathology worldwide, is characterized by a vaginal $\mathrm{pH}$ of $>4.5$ and by an overgrowth of anaerobic bacteria (Eschenbach, 1993). An increase in vaginal $\mathrm{pH}$ is detrimental to the survival of lactobacilli; therefore, local acidification with lactic acid or lactobacilli is useful for restoration of the vaginal ecosystem (Melis et al., 2000).

The characteristics of lactobacilli, i.e. their ability to colonize different hosts (Kotarski \& Savage, 1979), led to the isolation of strains from the human vagina (Ocaña et al., 1999a) and their use in vaginal probiotic products (Ocaña et al., 1999b, c,

Abbreviation: $\mathrm{LDH}$, lactic acid dehydrogenase. d). Optimal culture conditions to obtain the highest growth of the selected micro-organisms (Juárez Tomás et al., 2002a), as well as a higher degree of bacteriocins (Juárez Tomás et al., $2002 b$ ), were reported.

Lactic acid production by lactobacilli that are used by food industries has been studied extensively (Passos et al., 1994; Kylä-Nikkilä et al., 2000). However, there are only a few reports concerning the growth and lactic acid production by vaginal lactobacilli (Boskey et al., 1999, 2001). In this paper, the capability of autochthonous strains of vaginal lactobacilli to inhibit growth of different pathogenic micro-organisms was analysed. Lactobacillus acidophilus CRL 1259 was selected to study the effects of different culture conditions on biomass and lactic acid production. The inhibitory effect of lactic acid produced by this strain on the growth of a human uropathogenic Escherichia coli strain was also determined.

\section{METHODS}

Micro-organisms and culture media. Vaginal lactobacilli strains $(n=134)$ that had been isolated previously from vaginal samples of healthy women from 19 to 45 years old from Tucumán, Argentina (Ocaña et al., 1999a), were studied. The following human uropathogenic micro-organisms were employed: E. coli, Klebsiella sp., group B Streptococcus sp., Enterococcus faecalis, Staphylococcus aureus, Neisseria gonorrhoeae, Candida sp. and Gardnerella sp. (provided by the Instituto 
de Microbiología 'Luis Verna' of the Universidad Nacional de Tucumán) and Streptococcus agalactiae ATCC 27956 (CRL 1022) (from the American Type Culture Collection). The strain of E. coli that was used for mixed cultures had the following urovirulence characteristics: type $\mathrm{P}$ fimbriae (as demonstrated by the haemagglutination test), production of haemolysins and pyelonephritogenic effects, as tested in mice (SilvaRuiz et al., 2001).

All micro-organisms were stored in milk/yeast extract (130 g non-fat milk, $5 \mathrm{~g}$ yeast extract and $10 \mathrm{~g}$ glucose $1^{-1}$ ) at $-20{ }^{\circ} \mathrm{C}$, except for $N$. gonorrhoeae and G. vaginalis, which were used as soon as they had been isolated. Stored lactobacilli and pathogens were subcultured three times for $12 \mathrm{~h}$ in LAPTg (yeast extract/peptone/tryptone/Tween 80/glucose) broth (Raibaud et al., 1973), prior to screening for production of inhibitory substances.

Before the growth experiments, L. acidophilus CRL 1259 was subcultivated in either MRS (De Man-Rogosa-Sharpe; De Man et al., 1960) broth (Biokar Diagnostics) or LAPTg broth. The inoculum was prepared as described previously (Juárez Tomás et al., 2002a).

Screening for production of inhibitory levels of antagonistic substances. The effects of supernatant fluid of 134 strains of vaginal lactobacilli on the growth of uropathogens were studied by employing the plate-diffusion technique (Jack et al., 1995). Briefly, LAPTg agar plates (standardized volume, $15 \mathrm{ml}$ LAPTg broth with $1 \%$ agar) with $10^{6}-10^{7}$ c.f.u. $\mathrm{ml}^{-1}$ of each pathogen were prepared, as described previously (Ocaña et al., 1999b). Standardized aliquots (25 $\mu \mathrm{l})$ of non- treated and neutralized supernatant of lactobacilli were placed into holes (standardized diameter, $4 \mathrm{~mm}$ ) in the pathogen-inoculated plates. The plates were incubated for $5 \mathrm{~h}$ at room temperature and then for $24 \mathrm{~h}$ at $37^{\circ} \mathrm{C}$. A clear inhibition zone of $\geqslant 6 \mathrm{~mm}$ diameter was defined as a positive result. Control assays with the culture medium (LAPTg broth, $\mathrm{pH} 4$ or $6 \cdot 5$ ) were also performed.

Growth and lactic acid production by L. acidophilus CRL 1259. Combinations of two culture media (LAPTg or MRS broth), three temperatures $\left(30,37\right.$ or $\left.44^{\circ} \mathrm{C}\right)$ and three initial $\mathrm{pH}$ values $(5 \cdot 0,6 \cdot 5$ or $8.0)$ were evaluated. Growth experiments, including preparation of culture media, $\mathrm{pH}$ determination and quantification of c.f.u. $\mathrm{ml}^{-1}$, were performed as described previously (Juárez Tomás et al., 2002b).

Amounts of D- and L-lactic acid produced during growth were analysed enzymically by using a lactic acid dehydrogenase (LDH) commercial test kit (Boehringer Mannheim). The assay was performed on supernatant fluids of lactobacilli cultures that were obtained by centrifugation at 5000 r.p.m. for $10 \mathrm{~min}$.

Estimation of growth curves. Growth parameters, estimated by using the four-parameter Gompertz model, are: $\log \left(\text { c.f.u. } \mathrm{ml}^{-1}\right)_{\mathrm{t}}$ (cell concentration at time $t) ; \log \left(\text { c.f.u. } \mathrm{ml}^{-1}\right)_{0}$ (cell concentration at time zero); $A$ [increase of biomass between $\log$ (c.f.u. $\left.\mathrm{ml}^{-1}\right)_{0}$ and $\log$ (c.f.u. $\left.\mathrm{ml}^{-1}\right)_{\max }$ ]; $\mu$ [maximum specific growth rate $\left(\mathrm{h}^{-1}\right)$ ]; and $\lambda$ [duration time of lag phase (h)] (Zwietering et al., 1990; Juárez Tomás et al., 2002a).
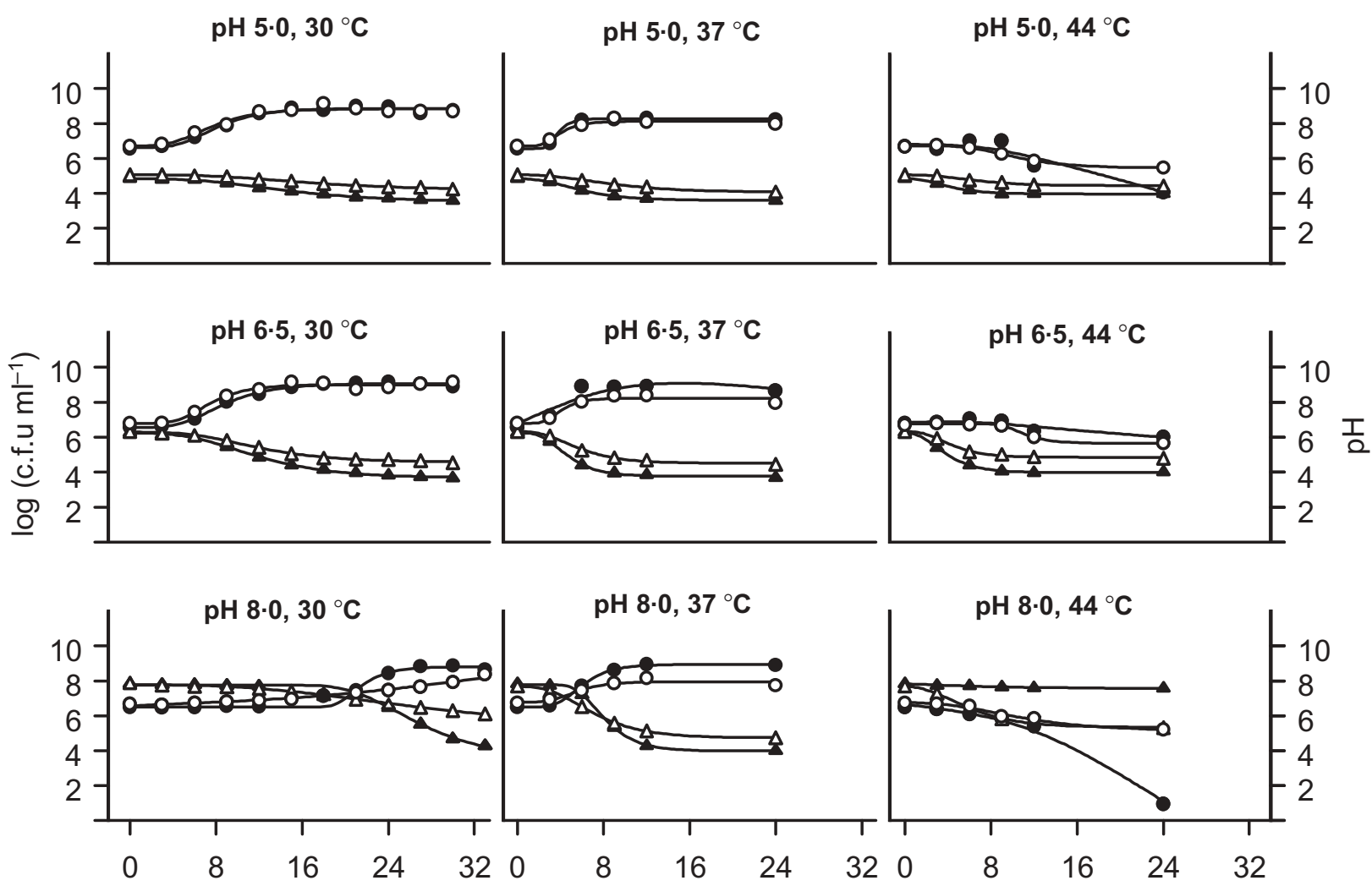

Time (h)

Fig. 1. Kinetics of growth and decrease in $\mathrm{pH}$ of $\mathrm{L}$. acidophilus CRL 1259 under different culture conditions. Log c.f.u. $\mathrm{ml}^{-1}$ in $\mathrm{LAPTg}$ broth $(\mathbf{O})$ and MRS broth $(\bigcirc)$; pH modifications in LAPTg broth $(\mathbf{\Delta})$ and MRS broth $(\triangle)$. 
Standard errors (SE) of the growth parameters were calculated by the bootstrapping method (Efron, 1982; Huet et al., 1996; Juárez Tomás et al., 2002b).

To determine the statistical significance of the effects of each growth medium (LAPTg or MRS broth) on growth parameters, the differences between parameters were included directly in the equation of the model, in order to estimate confidence intervals (data not shown).

To evaluate multivariate effects of different conditions (temperature, initial $\mathrm{pH}$ and culture medium) on growth parameters, the non-linear mixed-effects model [as proposed by Lindstrom \& Bates (1990)] was applied by using restricted maximum-likelihood.

For analyses and graphical presentations, the statistical programs SAS 8.2, SPSS 10 and S-Plus 2000 were used.

Mixed cultures of L. acidophilus CRL 1259 and E. coli. Mixed cultures of L. acidophilus CRL 1259 and E. coli were performed in LAPTg broth at $37^{\circ} \mathrm{C}$. MRS broth was not used, as E. coli grew slowly in this medium. Inocula contained $10^{5}-10^{6}$ c.f.u. $\mathrm{ml}^{-1}$ for E. coli and $10^{6}-10^{7}$ c.f.u. $\mathrm{ml}^{-1}$ for lactobacilli. Viable cell counts were determined by the plate-dilution method by using selective culture media: MacConkey agar for E. coli and lactobacillus selective medium (LBS) for lactobacilli. MacConkey and LBS plates were incubated at $37^{\circ} \mathrm{C}$ for $48 \mathrm{~h}$ under aerobic and microaerophilic conditions, respectively.

The $\mathrm{pH}$ values and levels of $\mathrm{D}$ - and L-lactic acids in pure and mixed cultures were determined as described above. All experiments were performed in triplicate. Means of the data are represented in the graphs.

Determination of the MIC of lactic acid. The diffusion method was applied to agar plates that were prepared as described above and contained uropathogenic E. coli. Decreasing concentrations of lactic acid were evaluated $(111-1 \cdot 1 \mathrm{mM})$. The MIC was defined as the lowest amount of lactic acid that produced a clear inhibition zone.

\section{RESULTS}

\section{Inhibition of pathogens by lactobacilli supernatants}

Among the 134 strains of vaginal lactobacilli isolated previously (Ocaña et al., 1999a), only Lactobacillus brevis CRL 1335 and L. acidophilus strains CRL 1259, CRL 1307, CRL 1320 and CRL 1324 were able to inhibit the growth of E. coli, Staphylococcus aureus, Streptococcus agalactiae, Enterococcus faecalis, Klebsiella sp., N. gonorrhoeae and G. vaginalis. Inhibition haloes were shown to be produced by the low $\mathrm{pH}$ of the lactobacilli supernatants, as they disappeared when the supernatants were neutralized. L. acidophilus CRL 1259 produced bigger inhibition haloes on the pathogen plates (data not shown).

Lactobacillus salivarius subsp. salivarius CRL 1328 was able to inhibit the growth of E. coli, Klebsiella sp., G. vaginalis, Staphylococcus aureus and Streptococcus agalactiae by the effect of $\mathrm{pH}$, and $\mathrm{N}$. gonorrhoeae and Enterococcus faecalis by a bacteriocin-like substance that was reported previously (Ocaña et al., 1999d). Lactobacillus crispatus CRL 1266 only inhibited the growth of $S$. aureus by the effect of $\mathrm{H}_{2} \mathrm{O}_{2}$ (a catalase-sensitive metabolite) (Ocaña et al., 1999b).

Table 1. Estimation of growth parameters of $L$. acidophilus CRL 1259 under different growth conditions by application of the Gompertz model

Parameters of the Gompertz model $( \pm \mathrm{SE})$ : $\log \left(\text { c.f.u. } \mathrm{ml}^{-1}\right)_{0}$, initial biomass; $A$, increase between initial and final biomass; $\mu$, maximum specific growth rate; $\lambda$, lag phase.

\begin{tabular}{|c|c|c|c|c|}
\hline Conditions & $\log \left(\text { c.f.u. } \mathrm{ml}^{-1}\right)_{0}$ & $A$ & $\boldsymbol{\mu}\left(\mathbf{h}^{-1}\right)$ & $\lambda(\mathbf{h})$ \\
\hline \multicolumn{5}{|l|}{$30^{\circ} \mathrm{C}$} \\
\hline \multicolumn{5}{|l|}{ pH $5 \cdot 0$} \\
\hline LAPTg & $6 \cdot 62 \pm 0 \cdot 27$ & $2 \cdot 23 \pm 0 \cdot 28$ & $0 \cdot 30 \pm 0 \cdot 28$ & $4 \cdot 23 \pm 1.98$ \\
\hline MRS & $6.72 \pm 0.66$ & $2 \cdot 11 \pm 0 \cdot 72$ & $0 \cdot 27 \pm 0 \cdot 29$ & $3.55 \pm 2.73$ \\
\hline \multicolumn{5}{|l|}{ pH $6 \cdot 5$} \\
\hline LAPTg & $6 \cdot 56 \pm 0 \cdot 25$ & $2 \cdot 51 \pm 0 \cdot 27$ & $0 \cdot 30 \pm 0 \cdot 09$ & $4 \cdot 30 \pm 1 \cdot 61$ \\
\hline MRS & $6 \cdot 79 \pm 0 \cdot 14$ & $2 \cdot 21 \pm 0 \cdot 17$ & $0 \cdot 35 \pm 0 \cdot 28$ & $4 \cdot 16 \pm 1 \cdot 83$ \\
\hline \multicolumn{5}{|l|}{$\mathrm{pH} 8 \cdot 0$} \\
\hline LAPTg & $6 \cdot 51 \pm 0.02$ & $2 \cdot 29 \pm 0 \cdot 10$ & $0 \cdot 48 \pm 0 \cdot 26$ & $19 \cdot 02 \pm 2.66$ \\
\hline MRS & $6.71 \pm 0.06$ & $3 \cdot 00 \pm 0 \cdot 29$ & $0 \cdot 08 \pm 0 \cdot 01$ & $13.90 \pm 2.09$ \\
\hline \multicolumn{5}{|l|}{$37^{\circ} \mathrm{C}$} \\
\hline \multicolumn{5}{|l|}{ pH $5 \cdot 0$} \\
\hline LAPTg & $6 \cdot 56 \pm 0 \cdot 32$ & $1 \cdot 70 \pm 0 \cdot 32$ & $0 \cdot 80 \pm 0 \cdot 23$ & $2 \cdot 64 \pm 1 \cdot 42$ \\
\hline MRS & $6 \cdot 70 \pm 0 \cdot 37$ & $1 \cdot 42 \pm 0 \cdot 39$ & $0 \cdot 41 \pm 0 \cdot 29$ & $2 \cdot 15 \pm 1 \cdot 71$ \\
\hline \multicolumn{5}{|l|}{ pH 6.5} \\
\hline LAPTg & $6.57 \pm 0.99$ & $2 \cdot 28 \pm 1 \cdot 08$ & $1 \cdot 00 \pm 0 \cdot 07$ & $2.33 \pm 1.05$ \\
\hline MRS & $6 \cdot 79 \pm 0 \cdot 28$ & $1 \cdot 44 \pm 0 \cdot 33$ & $0 \cdot 43 \pm 0 \cdot 27$ & $2 \cdot 32 \pm 1 \cdot 34$ \\
\hline \multicolumn{5}{|l|}{$\mathrm{pH} 8 \cdot 0$} \\
\hline LAPTg & $6 \cdot 51 \pm 0 \cdot 34$ & $2 \cdot 44 \pm 0 \cdot 35$ & $0 \cdot 49 \pm 0 \cdot 22$ & $3 \cdot 52 \pm 0.98$ \\
\hline MRS & $6 \cdot 79 \pm 0 \cdot 31$ & $1 \cdot 16 \pm 0 \cdot 54$ & $0 \cdot 23 \pm 0 \cdot 37$ & $2 \cdot 89 \pm 1.66$ \\
\hline
\end{tabular}




\section{Optimization of growth conditions of $L$. acidophilus CRL 1259}

Fig. 1 shows the growth and $\mathrm{pH}$ decrease of L. acidophilus CRL 1259 in LAPTg and MRS broth under different combinations of initial $\mathrm{pH}$ and temperature. At $44^{\circ} \mathrm{C}$, the viability of the micro-organisms decreased after a short time. In this case, growth-parameter estimation and lactic acid determination were not performed.

Values of the growth parameters obtained varied with the culture conditions tested (Table 1). For all conditions tested, LAPTg broth supported higher growth than MRS broth, but this was statistically significant only at an initial $\mathrm{pH}$ of 8.0 and $37^{\circ} \mathrm{C}$. For all growth media and $\mathrm{pH}$ values assayed, growth rates were higher at $37^{\circ} \mathrm{C}$. Length of lag phases was inversely related to temperature. When the two types of broth were incubated at the same temperature, lag phases were longer at an initial $\mathrm{pH}$ of $8 \cdot 0$.

According to statistical analysis performed with the nonlinear mixed-effects model, initial $\mathrm{pH}$ of the culture medium and temperature of incubation showed significant effects $(P<0 \cdot 05)$ on all growth parameters tested (increase of biomass, growth rate and lag phase). However, culture medium only affected the final biomass significantly.

Optimal conditions for the growth of $L$. acidophilus were LAPTg broth with an initial $\mathrm{pH}$ of 6.5 and at $37^{\circ} \mathrm{C}$. Under these conditions, the highest biomass and growth rates, together with shorter lag phases, were obtained. Similar growth was observed in LAPTg broth at $37^{\circ} \mathrm{C}$ and an initial $\mathrm{pH}$ of $8 \cdot 0$.
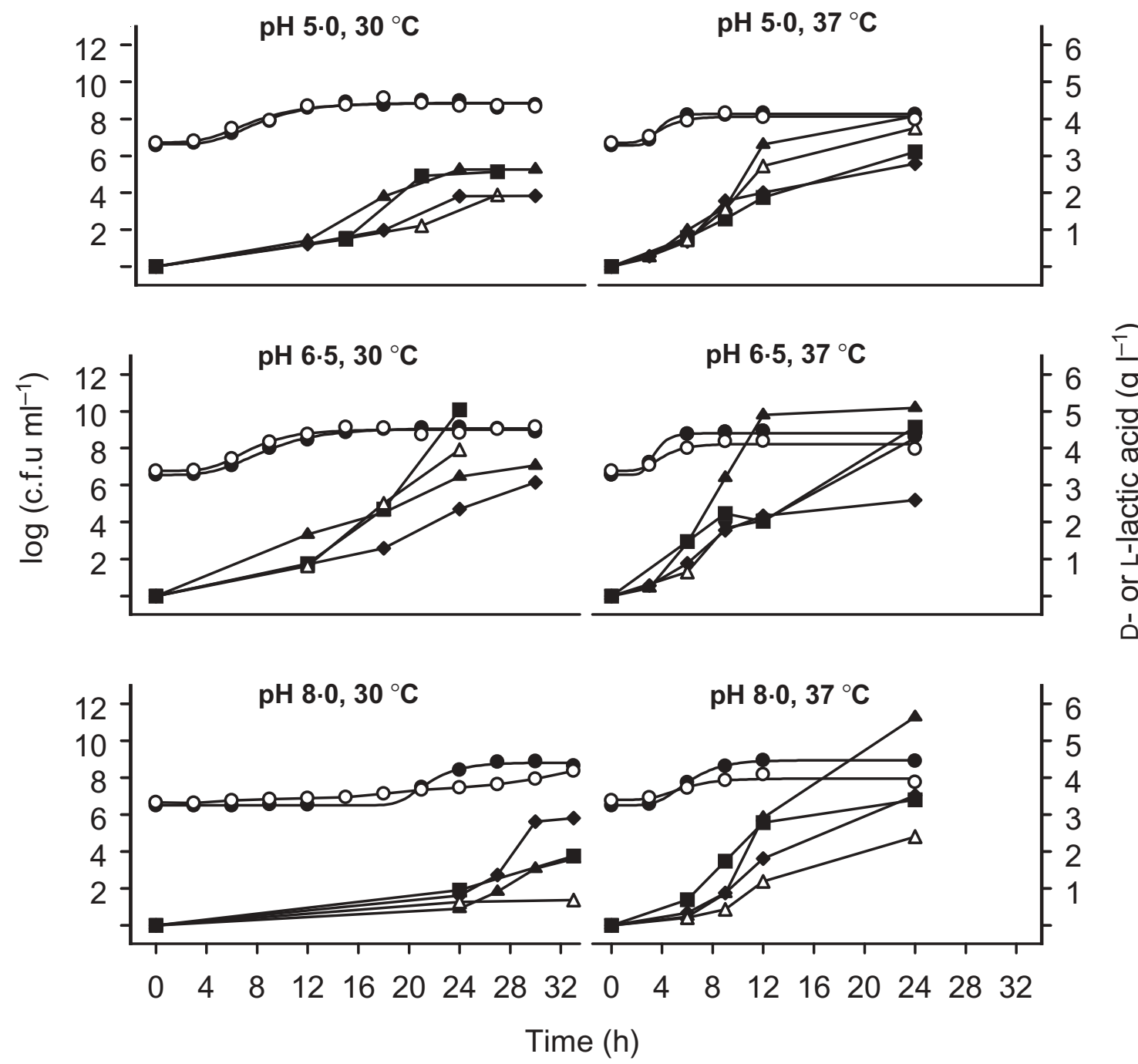

Fig. 2. Kinetics of growth and lactic acid production by L. acidophilus CRL 1259 under different culture conditions. Log c.f.u. $\mathrm{ml}^{-1}$ in LAPTg broth $(\mathbf{O})$ and MRS broth $(\bigcirc)$; levels of D-lactic acid in LAPTg broth $(\mathbf{\Delta})$ and MRS broth $(\triangle)$; levels of L-lactic acid in LAPTg broth $(\bullet)$ and MRS broth $(\boldsymbol{\square})$. 


\section{pH decrease by L. acidophilus CRL 1259 under different growth conditions}

Decrease in $\mathrm{pH}$ and acidification rates were significantly higher in LAPTg broth than in MRS broth, due to the higher ion content and buffering capacity of the latter medium (Fig. 1). The difference between initial and final $\mathrm{pH}$ of $L$. acidophilus cultures was related directly to initial $\mathrm{pH}$ when LAPTg or MRS broth was incubated at the same temperature. The same behaviour was observed with acidification rates. The largest decrease in $\mathrm{pH}$ was obtained in LAPTg broth at an initial $\mathrm{pH}$ of 6.5 or 8.0 and at $37^{\circ} \mathrm{C}$. This effect was also observed at $30^{\circ} \mathrm{C}$, but after a longer incubation time.

\section{Lactic acid production by L. acidophilus CRL 1259}

Relative proportions of D- and L-lactic acid varied according to the growth medium used (Fig. 2). In general, levels of the D-isomer produced in LAPTg (expressed as $\mathrm{g}^{-1}$; Fig. 2) were higher than those of the L-isomer. An inverse relationship was observed in MRS broth.

In both growth media at different initial $\mathrm{pH}$ levels, production of the $\mathrm{L}$ - and D-isomers was maximal at $37^{\circ} \mathrm{C}$. When the two types of broth were incubated at the same temperature (except for LAPTg broth at $37^{\circ} \mathrm{C}$ ), higher amounts of D- and L-lactic acid (expressed as $\mathrm{g}^{-1}$ ) were observed at $\mathrm{pH} 6 \cdot 5$.
Maximal concentrations of D-lactic acid were obtained in LAPTg broth at $37^{\circ} \mathrm{C}$ and $\mathrm{pH} 6.5\left(5.09 \mathrm{~g} \mathrm{l}^{-1}\right.$ after $12 \mathrm{~h}$ culture) or $8.0\left(5.64 \mathrm{~g} \mathrm{l}^{-1}\right.$ after $\left.24 \mathrm{~h}\right)$. The best conditions for production of L-lactic acid were MRS broth at an initial $\mathrm{pH}$ of 6.5 and 30 or $37^{\circ} \mathrm{C}\left(5.04\right.$ and $4.57 \mathrm{~g} \mathrm{l}^{-1}$, respectively, both after $24 \mathrm{~h}$ culture).

Levels of D-, L- and total lactic acid produced by $10^{7}$ c.f.u. were higher in MRS broth than in LAPTg broth (Table 2). This indicates that $L$. acidophilus is more active, from a metabolic point of view, in MRS broth.

\section{Mixed cultures of $L$. acidophilus CRL 1259 and E. coli}

Results from mixed cultures of L. acidophilus CRL 1259 and E. coli are shown in Fig. 3. When using an E. coli inoculum of $1 \cdot 01 \times 10^{6}$ c.f.u. $\mathrm{ml}^{-1}$, complete inhibition of pathogen growth was observed after $21 \mathrm{~h}$, whereas when the inoculum of E. coli was $2.4 \times 10^{5}$ c.f.u. $\mathrm{ml}^{-1}, 100 \%$ inhibition of pathogen growth was observed after $15 \mathrm{~h}$.

Levels of L- and D-lactic acid produced by lactobacilli, either in pure or mixed culture, were two times higher than those produced by pure E. coli cultures at both inoculum levels. In mixed cultures, the concentrations were $5 \cdot 5 \mathrm{~g} \mathrm{l}^{-1}$ for D-lactic acid and $2 \cdot 8 \mathrm{~g}^{-1}$ for L-lactic acid.

Table 2. Mean values of maximal lactic acid concentration produced by $L$. acidophilus CRL 1259 under different culture conditions

\begin{tabular}{|c|c|c|c|c|}
\hline \multirow[t]{2}{*}{ Conditions } & \multirow[t]{2}{*}{ Total lactic acid $\left(\mathrm{g} \mathrm{l}^{-1}\right)$} & \multicolumn{3}{|c|}{ Lactic acid $\left[\mathrm{mg} \mathrm{ml}^{-1}\left(10^{7} \text { c.f.u. }\right)^{-1}\right]$} \\
\hline & & D-isomer & L-isomer & Total \\
\hline \multicolumn{5}{|l|}{$30^{\circ} \mathrm{C}$} \\
\hline \multicolumn{5}{|l|}{$\mathrm{pH} 5 \cdot 0$} \\
\hline LAPTg & $4 \cdot 54$ & $0 \cdot 04$ & $0 \cdot 03$ & $0 \cdot 07$ \\
\hline MRS & $4 \cdot 51$ & $0 \cdot 03$ & $0 \cdot 05$ & $0 \cdot 08$ \\
\hline \multicolumn{5}{|l|}{$\mathrm{pH} 6 \cdot 5$} \\
\hline LAPTg & $6 \cdot 61$ & $0 \cdot 04$ & $0 \cdot 04$ & $0 \cdot 08$ \\
\hline MRS & $9 \cdot 00$ & $0 \cdot 05$ & $0 \cdot 07$ & $0 \cdot 12$ \\
\hline \multicolumn{5}{|l|}{ pH 8.0 } \\
\hline LAPTg & $4 \cdot 70$ & $0 \cdot 04$ & $0 \cdot 07$ & $0 \cdot 11$ \\
\hline MRS & $2 \cdot 56$ & $0 \cdot 03$ & $0 \cdot 08$ & $0 \cdot 11$ \\
\hline \multicolumn{5}{|l|}{$37^{\circ} \mathrm{C}$} \\
\hline \multicolumn{5}{|l|}{$\mathrm{pH} 5 \cdot 0$} \\
\hline LAPTg & $6 \cdot 85$ & $0 \cdot 23$ & $0 \cdot 15$ & $0 \cdot 38$ \\
\hline MRS & $6 \cdot 85$ & $0 \cdot 39$ & $0 \cdot 33$ & $0 \cdot 72$ \\
\hline \multicolumn{5}{|l|}{ pH $6 \cdot 5$} \\
\hline LAPTg & $7 \cdot 69$ & $0 \cdot 09$ & $0 \cdot 05$ & $0 \cdot 14$ \\
\hline MRS & $8 \cdot 85$ & $0 \cdot 48$ & $0 \cdot 51$ & 0.99 \\
\hline \multicolumn{5}{|l|}{$\mathrm{pH} 8 \cdot 0$} \\
\hline LAPTg & $9 \cdot 16$ & $0 \cdot 04$ & $0 \cdot 02$ & 0.06 \\
\hline MRS & $5 \cdot 80$ & $0 \cdot 41$ & 0.59 & $1 \cdot 00$ \\
\hline
\end{tabular}

Maximal amounts of lactic acid were obtained between 24 and $30 \mathrm{~h}$ culture at $30^{\circ} \mathrm{C}$ or after $24 \mathrm{~h}$ for cultures at $37^{\circ} \mathrm{C}$. 


\section{Determination of MIC}

The MIC of lactic acid for E. coli was $55.49 \mathrm{mM}$ (equivalent to $\left.5.0 \mathrm{~g} \mathrm{l}^{-1}\right)$. This value was lower than the lactic acid levels produced by L. acidophilus CRL 1259 after $9 \mathrm{~h}$ in mixed cultures, when pathogen viability decreased.

\section{DISCUSSION}

Primary selection of potentially probiotic strains must be performed through the application of 'in vitro' techniques. Production of antagonistic substances (organic acids, hydro- gen peroxide or bacteriocins) against pathogens is a technique that is widely used (McLean \& Rosenstein, 2000; Aroutcheva et al., 2001; Strus et al., 2002). Among 134 vaginal Lactobacillus strains isolated previously in our laboratory (Ocaña et al., 1999a), only six strains were able to inhibit all the pathogens under study, except for $C$. albicans. Inhibition of pathogenic micro-organisms that cause urogenital infections increases the relevance of these wild strains of Lactobacillus for use in probiotic products.

In this study, we employed two culture media that are commonly used for lactobacilli and $\mathrm{pH}$ levels other than 4

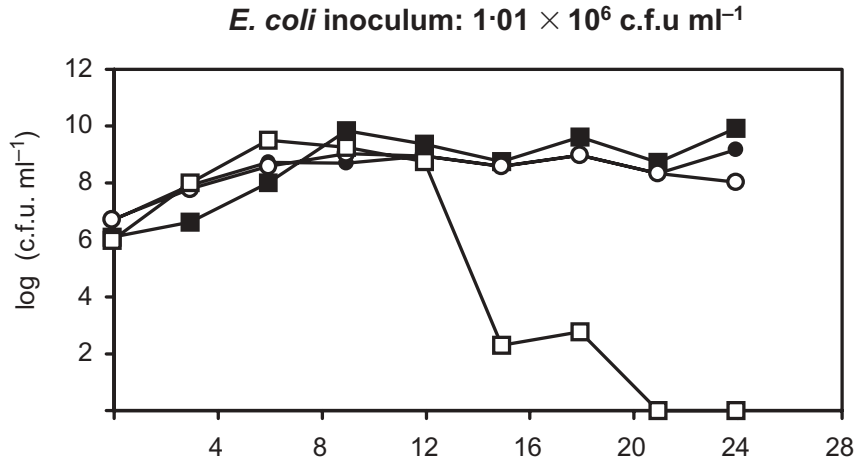

E. coli inoculum: $1.01 \times 10^{6}$ c.f.u $\mathrm{ml}^{-1}$

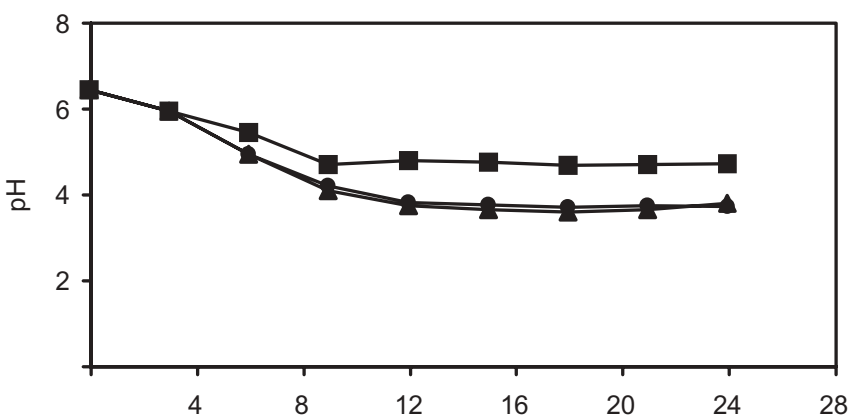

E. coli inoculum: $1.01 \times 10^{6}$ c.f.u $\mathrm{ml}^{-1}$

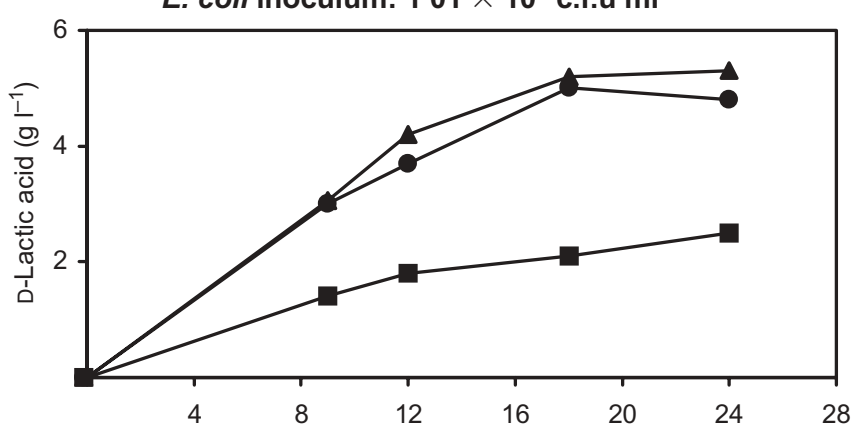

E. coli inoculum: $2.4 \times 10^{5}$ c.f.u ml-1

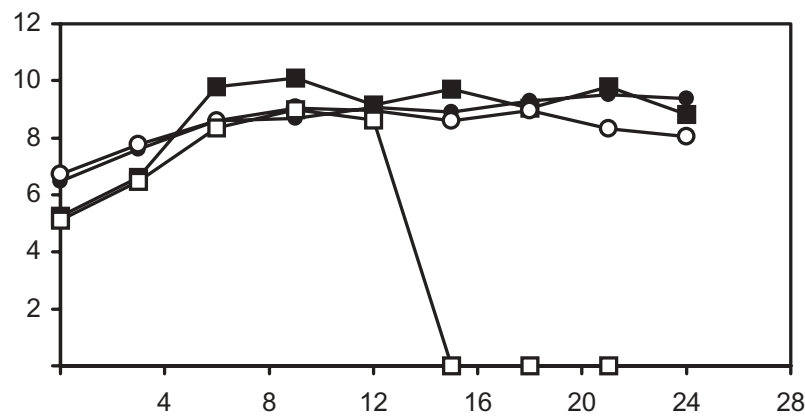

E. coli inoculum: $2.4 \times 10^{5}$ c.f.u $\mathrm{ml}^{-1}$

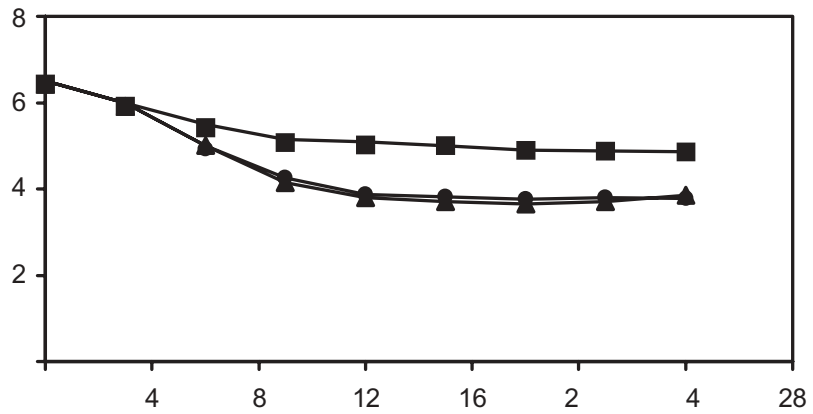

E. coli inoculum: $1.01 \times 10^{6}$ c.f.u $\mathrm{ml}^{-1}$

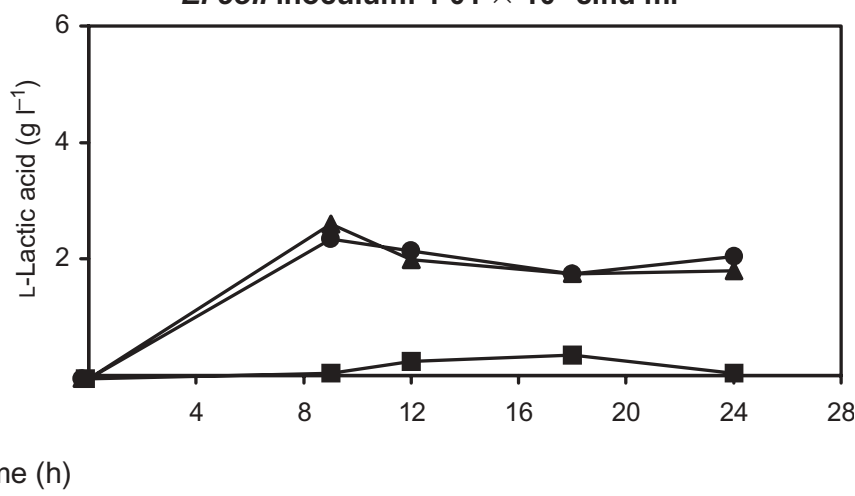

Fig. 3. Pure and mixed cultures of $L$. acidophilus $C R L 1259$ and E. coli. Log c.f.u. $\mathrm{ml}^{-1}$, pH or lactic acid levels of $E$. coli in pure ( $\left.\boldsymbol{\square}\right)$ or mixed $(\square)$ cultures; log c.f.u. $\mathrm{ml}^{-1}$, pH or lactic acid levels of $L$. acidophilus in pure $(\mathbf{O})$ or mixed $(\bigcirc)$ cultures; $\mathrm{pH}$ or lactic acid levels in mixed cultures $(\mathbf{\Lambda})$. 
(the vaginal $\mathrm{pH}$ ), instead of a chemically defined medium designed to simulate genital secretions (Geshnizgani \& Onderdock, 1992). The objective of the present work was not to simulate vaginal conditions, but to assess the most favourable conditions to produce the highest biomass of $L$. acidophilus CRL 1259 in the shortest time and to evaluate factors that affect the production of lactic acid in laboratory assays.

Under conditions of good growth for $L$. acidophilus CRL 1259 , the final $\mathrm{pH}$ values reached $(3 \cdot 5-4 \cdot 6)$ were comparable to those determined in the healthy vagina (Andersch et al., 1986; Tevi-Bénissan et al., 1997). Boskey et al. (1999) reported that eight vaginal Lactobacillus strains acidified the growth medium to an asymptotic $\mathrm{pH}$ of $3 \cdot 2-4 \cdot 8$. This fact suggests that lactobacilli create an acidic environment that can inhibit the growth of other micro-organisms.

Production of D- and L-lactic acid by L. acidophilus CRL 1259 was dependent on the three factors tested (growth medium, pH and temperature). Kylä-Nikkilä et al. (2000) reported that the level of production of each isomer only seemed to be dependent to a limited extent on change in expression of the genes responsible for D- and L-LDH. These authors observed different kinetics of production of D- and L-lactic acid by Lactobacillus helveticus CNRZ32 and suggested that different intracellular conditions can change either the catalytic activity of enzymes (D- or L-LDH) or their affinity for the substrate (pyruvate).

Optimal $\mathrm{pH}$ and temperature for maximum production of lactic acid were the same as those required for growth. Levels of total lactic acid produced by this micro-organism under different culture conditions $\left(2 \cdot 56-9 \cdot 16 \mathrm{~g} \mathrm{l}^{-1}\right)$ were higher than those found in vaginal secretions of women $(0 \cdot 90-4 \cdot 00$ $\mathrm{g} \mathrm{l}^{-1}$ ) (Boskey et al., 2001).

Mixed cultures showed that $L$. acidophilus CRL 1259 was able to inhibit the growth of $E$. coli at different incubation times, depending on the initial inoculum of pathogen. The final $\mathrm{pH}$ reached in mixed cultures was around $4 \cdot 0$. Stamey \& Timothy (1975) observed that when the vaginal $\mathrm{pH}$ is $<4 \cdot 5$, colonization of the introitus by $E$. coli is not frequent, whereas the frequency of urinary tract infections is higher when the $\mathrm{pH}$ is $>4.5$.

In vitro studies of interactions between organisms are oversimplified, compared with the complexity of human mucosal flora. Although its relevance to the in vivo situation is questionable, in vitro experimentation provides an approach for determination of the ability of lactobacilli to inhibit the growth of pathogens. In an animal model, L. fermentum CRL 1058 contained in agarose beads completely inhibited E. coli colonization of the urinary tract of mice (Silva-Ruiz et al., 1993, 1996; Nader de Macías et al., 1996). Reid et al. (1985) also reported that vaginal instillation of lactobacilli in mice protected against uropathogenic E. coli colonization and later reported similar observations for colonization of the human vagina (Reid et al., 1992).

In summary, the results of this study demonstrate that vaginal Lactobacillus strains isolated from Tucumán, Argentina, are able to inhibit the growth of uropathogens by the effect of lactic acid. The results of growth, lactic acid production and mixed cultures with $E$. coli strongly suggest that $L$. acidophilus CRL 1259, alone or combined with other strains of lactobacilli, can be used in probiotic products to prevent infections of the urogenital tract.

\section{ACKNOWLEDGEMENTS}

This paper was supported by Carrillo-Oñativia grants (from the Subsecretaría de Ciencia y Tecnología del Ministerio de Salud Pública de la República Argentina) with PID-BID 385 from CONICET (Consejo Nacional de Investigaciones Científicas y Técnicas -Argentina). B. W. is supported by BMBF, Germany, and by SETCIP (bilateral co-operation project ARG 99/025). We thank Elena Bru de Labanda for her help in the experimental design of this study.

\section{REFERENCES}

Andersch, B., Forssman, L., Lincoln, K. \& Tortensson, P. (1986). Treatment of bacterial vaginosis with an acid cream: a comparison between the effect of lactate-gel and metronidazole. Gynecol Obstet Invest 21, 19-25.

Aroutcheva, A., Gariti, D., Simon, M., Shott, S., Faro, J., Simoes, J. A., Gurguis, A. \& Faro, S. (2001). Defense factors of vaginal lactobacilli. Am J Obstet Gynecol 185, 375-379.

Boskey, E. R., Telsch, K. M., Whaley, K. J., Moench, T. R. \& Cone, R. A. (1999). Acid production by vaginal flora in vitro is consistent with the rate and extent of vaginal acidification. Infect Immun 67, 5170-5175.

Boskey, E. R., Cone, R. A., Whaley, K. J. \& Moench, T. R. (2001). Origins of vaginal acidity: high $\mathrm{D} / \mathrm{L}$ lactate ratio is consistent with bacteria being the primary source. Hum Reprod 16, 1809-1813.

De Man, J. C., Rogosa, M. \& Sharpe, M. E. (1960). A medium for the cultivation of lactobacilli. J Appl Bacteriol 23, 130-135.

Efron, B. (1982). The bootstrap. In The Jackknife, the Bootstrap, and Other Resampling Plans, pp. 27-36. Edited by B. Efron. Philadelphia, PA: Society for Industrial and Applied Mathematics.

Eschenbach, D. A. (1993). History and review of bacterial vaginosis. Am J Obstet Gynecol 169, 441-445.

Geshnizgani, A. M. \& Onderdock, A. B. (1992). Defined medium simulating genital tract secretions for growth of vaginal microflora. J Clin Microbiol 30, 1323-1326.

Hanna, N. F., Taylor-Robinson, D., Kalodiki-Karamanoli, M., Harris, J. R. \& McFadyen, I. R. (1985). The relation between vaginal $\mathrm{pH}$ and the microbiological status in vaginitis. Br J Obstet Gynaecol 92, 1267-1271.

Huet, S., Bouvier, A., Gruet, M.-A. \& Jolivet, E. (1996). Accuracy of estimators, confidence intervals and tests. In Statistical Tools for Nonlinear Regression, pp. 29-59. New York: Springer.

Jack, R. W., Tagg, J. R. \& Ray, B. (1995). Bacteriocins of Gram-positive bacteria. Microbiol Rev 59, 171-200.

Juárez Tomás, M. S., Bru de Labanda, E., de Ruiz Holgado, A. P. \& Nader-Macias, M. E. (2002a). Estimation of vaginal probiotic lactobacilli growth parameters with the application of the Gompertz model. Can J Microbiol 48, 82-92.

Juárez Tomás, M. S., Bru, E., Wiese, B., de Ruiz Holgado, A. A. P. \& Nader-Macias, M. E. (2002b). Influence of $\mathrm{pH}$, temperature and culture media on the growth and bacteriocin production by vaginal Lactobacillus salivarius CRL 1328. J Appl Microbiol 93, 714-724. 
Kotarski, S. F. \& Savage, D. C. (1979). Models for study of the specificity by which indigenous lactobacilli adhere to murine gastric epithelia. Infect Immun 26, 966-975.

Kylä-Nikkilä, K., Hujanen, M., Leisola, M. \& Palva, A. (2000). Metabolic engineering of Lactobacillus helveticus CNRZ32 for production of pure L-(+)-lactic acid. Appl Environ Microbiol 66, 3835-3841.

Lindstrom, M. J. \& Bates, D. M. (1990). Nonlinear mixed effects models for repeated measures data. Biometrics 46, 673-687.

McLean, N. W. \& Rosenstein, I. J. (2000). Characterisation and selection of a Lactobacillus species to re-colonise the vagina of women with recurrent bacterial vaginosis. J Med Microbiol 49, 543-552.

Melis, G. B., Ibba, M. T., Steri, B., Kotsonis, P., Matta, V. \& Paoletti, A. M. (2000). Role of $\mathrm{pH}$ as a regulator of vaginal physiological environment. Minerva Ginecol 52, 111-121 (in Italian).

Nader de Macías, M. E., de Ruiz, C. S., López de Bocanera, M. E. \& Pesce de Ruiz Holgado, A. A. (1996). Preventive and therapeutic effects of lactobacilli on urinary tract infections in mice. Anaerobe 2, 85-93.

Ocaña, V. S., Bru, E., de Ruiz Holgado, A. A. \& Nader-Macías, M. E. (1999a). Surface characteristics of lactobacilli isolated from human vagina. J Gen Appl Microbiol 45, 203-212.

Ocaña, V. S., Pesce de Ruiz Holgado, A. A. \& Nader-Macías, M. E. (1999b). Selection of vaginal $\mathrm{H}_{2} \mathrm{O}_{2}$-generating Lactobacillus species for probiotic use. Curr Microbiol 38, 279-284.

Ocaña, V. S., de Ruiz Holgado, A. A. \& Nader-Macías, M. E. (1999c). Growth inhibition of Staphylococcus aureus by $\mathrm{H}_{2} \mathrm{O}_{2}$-producing Lactobacillus paracasei subsp. paracasei isolated from the human vagina. FEMS Immunol Med Microbiol 23, 87-92.

Ocaña, V. S., Pesce de Ruiz Holgado, A. A. \& Nader-Macias, M. E. (1999d). Characterization of a bacteriocin-like substance produced by a vaginal Lactobacillus salivarius strain. Appl Environ Microbiol 65, $5631-5635$

Paavonen, J. (1983). Physiology and ecology of the vagina. Scand J Infect Dis Suppl 40, 31-35.

Passos, F. V., Fleming, H. P., Ollis, D. F., Felder, R. M. \& McFeeters, R. F. (1994). Kinetics and modeling of lactic acid production by Lactobacillus plantarum. Appl Environ Microbiol 60, 2627-2636.

Raibaud, P., Galpin, J. V., Ducluzeau, R., Mocquot, G. \& Oliver, G. (1973). Le genre Lactobacillus dans le tube digestif du rat. II. Caractères de souches heterofermentaires isolées de rats "Holo" et "Gnotoxéniques”. Ann Inst Pasteur Microbiol 124A, 2223-2235 (in French).
Redondo-López, V., Cook, R. L. \& Sobel, J. D. (1990). Emerging role of lactobacilli in the control and maintenance of the vaginal bacterial microflora. Rev Infect Dis 12, 856-872.

Reid, G., Chan, R. C., Bruce, A. W. \& Costerton, J. W. (1985). Prevention of urinary tract infection in rats with an indigenous Lactobacillus casei strain. Infect Immun 49, 320-324.

Reid, G., Bruce, A. W. \& Taylor, M. (1992). Influence of three-day antimicrobial therapy and Lactobacillus vaginal suppositories on recurrence of urinary tract infections. Clin Ther 14, 11-16.

Silva-Ruiz, C., Nader-Macias, M. E., Lopez-Bocanera, M. E. \& PesceRuiz Holgado, A. (1993). Lactobacillus fermentum administered in suspensions and in agarose beads to mice: a comparative study. Microbiol Alim Nutr 11, 391-397.

Silva-Ruiz, C., Lopez-Bocanera, M. E., Nader-Macias, M. E. \& PesceRuiz Holgado, A. (1996). Effect of lactobacilli and antibiotics on E. coli urinary infections in mice. Biol Pharm Bull 19, 88-93.

Silva-Ruiz, C., Rey, M. R., de Ruiz Holgado, A. P. \& Nader-Macias, M. E. (2001). Experimental administration of estradiol on the colonization of Lactobacillus fermentum and Escherichia coli in the urogenital tract of mice. Biol Pharm Bull 24, 127-134.

Stamey, T. A. \& Kaufman, M. F. (1975). Studies of introital colonization in women with recurrent urinary infections. II. A comparison of growth in normal vaginal fluid of common versus uncommom serogroups of Escherichia coli. J Urol 114, 264-267.

Stamey, T. A. \& Timothy, M. M. (1975). Studies of introital colonization in women with recurrent urinary infections. I. The role of vaginal $\mathrm{pH}$. J Urol 114, 261-263.

Strus, M., Malinowska, M. \& Heczko, P. B. (2002). In vitro antagonistic effect of Lactobacillus on organisms associated with bacterial vaginosis. J Reprod Med 47, 41-46.

Tevi-Bénissan, C., Bélec, L., Lévy, M., Schneider-Fauveau, V., Si Mohamed, A., Hallouin, M.-C., Matta, M. \& Grésenguet, G. (1997). In vivo semen-associated $\mathrm{pH}$ neutralization of cervicovaginal secretions. Clin Diagn Lab Immunol 4, 367-374.

Zwietering, M. H., Jongenburger, I., Rombouts, F. M. \& Van't Riet, K. (1990). Modeling of the bacterial growth curve. Appl Environ Microbiol 56, 1875-1881 